\title{
HOW TO MEASURE A QUALE
}

COMO MEDIR UM OUALE

\author{
OSVALDO PESSOA JR. ${ }^{1}$ \\ Universidade de São Paulo (USP) - Brasil \\ opessoa@usp.br
}

\begin{abstract}
According to the colored-brain thesis (or qualitative physicalism), sense data or qualia are real physical-chemical qualities, located inside the brain, possibly at a specific locus. Our hypothesis is that the seats of phenomenal consciousness have a structure and a materiality. According to the proposed view, a chromatic quale emerges when a certain pixel of the visual sensorium (the hypothetical subjective visual "screen", or Cartesian theater, with its specific materiality $\omega$ ) is fed with a certain pattern $\Sigma$ of spikes; a change in this pattern quickly changes the color that is subjectively generated. How could one manage to measure chromatic qualia? In principle, with nanoscopical techniques, one could capture all the patterns that fall on the sensorium, and transmit the information to other media. But this does not capture the qualia. However, if the patterns are made to fall on a tissue of the same kind, typically inside another person's brain, this other person will have roughly the same subjective experience as the first person. The model is used to explore two different situations involving qualia inversion. The paper also explores Cartesian materialism, and the claim that phenomenal time and space are identical to a region of physical time and space.
\end{abstract}

KEYWORDS: Colored-brain thesis. Materiality. Qualia. Qualitative physicalism. Sensorium.

RESUMO: De acordo com a tese do encéfalo colorido (ou fisicismo qualitativo), os dados dos sentidos ou qualia são qualidades fisicoquímicas reais, localizados no encéfalo, possivelmente em um local específico. Nossa hipótese é de que as sedes da consciência fenomênica têm uma estrutura e uma materialidade. De acordo com a visão proposta, um quale cromático emerge quando um certo píxel cromático do sensório visual (a hipotética "tela" visual subjetiva, ou teatro cartesiano, com sua materialidade específica $\omega$ ) é alimentado com um certo padrão $\Sigma$ de espículas; uma mudança neste padrão rapidamente altera a cor que é gerada subjetivamente. Como se poderia medir qualia cromáticos? Em princípio, com técnicas nanoscópicas, poder-se-ia capturar todos os padrôes que caem no sensório, e transmitir a informação para outro meio. Mas isso não captura os qualia. Porém, se os padrões caírem em um tecido da mesma espécie, tipicamente dentro do encéfalo de outra pessoa, então esta outra pessoa teria aproximadamente a mesma experiência subjetiva que a primeira. Este modelo é usado para explorer duas situações diferentes envolvendo inversão de qualia. O artigo também explora o materialismo cartesiano, e a afirmação de que o tempo e o espaço fenomênicos são idênticos a uma região do tempo e espaço físicos.

PALAVRAS-CHAVE: Tese do encéfalo colorido. Materialidade. Qualia. Fisicismo qualitativo. Sensório.

\footnotetext{
${ }^{1}$ Departamento de Filosofia (FFLCH) - Universidade de São Paulo (USP).
} 


\section{COLORED-BRAIN THESIS}

The colored-brain thesis (in Portuguese, "tese do encéfalo colorido", see PESSOA, 2017) is the name given by Leopold Stubenberg (1998, p. 169) to the view that phenomenal qualities, or qualia, are "properties of the brain". H.H. Price (1932, p. 127) referred to this thesis as the "hypothesis that sense data are cerebral". Price mentioned that the Hegelian philosopher F.H. Bradley had found it hard to believe that "when I smell a smell I am aware of the stinking state of my own nervous system", as the latter criticized Oxford philosopher Thomas Case, who had advocated the view. Case (1888, p. 33) characterized sense perception as the "the immediate apprehension of an internal physical object inside the nervous system of a sentient being". Case's position, however, was not materialist or physicalist, since he considered that God created and governs the world, and that the internal sensible object, which he took to be physical, was different from the "internal operation" which apprehends it, which he took to be "psychical".

The psychologist Edwin Boring came close to the thesis in 1933, as he argued for the mind-brain identity thesis in the interwar context of sense-data theory. According to U.T. Place (2000, p. 1), "Boring moreover, was himself apparently committed to combining the identity theory with a phenomenalist account of sensory qualities which on Leibniz's principle of the Identity of Indiscernibles would commit him to the view that certain brain events are literally green, high pitched, warm, sour or putrid, which for a philosopher would constitute an immediate knockdown reductio ad absurdum of his position".

In summary, according to the colored-brain thesis, which might also be called "qualitative physicalism", sense data or qualia are real physical-chemical qualities, yet to be treated by physical theory. Qualitative physicalism encompasses three main theses: ontic physicalism, the reality of qualia, and a mind-brain identity thesis.

The subjective greenness we experience as we look at an avocado is not in the fruit, but in our brain. If that is so, why doesn't a neurosurgeon ever see a green patch in our brain? The avocado appears green because of the wavelengths of light that it reflects, but our brain tissue does not have the same reflectance spectrum, so it doesn't appear green to an external observer. Subjective color has nothing to do with light (except for the detailed causal connection between the two): our brains are dark.

\section{WHAT IS PHYSICAL?}

There is no consensual definition of what "physical" is, but one feature to be encompassed by the term is that it involves processes in space, time, and scale (micro-macro). So if a chromatic quale is taken to be physical, it should be located inside the brain, possibly at a specific locus, and our phenomenal visual field should have a specific size, for example around the scale of $10 \mathrm{~cm}^{2}$, which is roughly the size of the retina (KOLB, 2007). We will adopt this localizationist hypothesis, although a more holistic view is also tenable. 
In the Mary's room thought experiment (JACKSON, 1982), it is assumed that inside her black-and-white room, Mary has complete "physical knowledge" about colors, that is, a complete linguistic-quantitative descriptive knowledge (which leaves out only knowledge by acquaintance of colors). The question is, does she know all there is to know about colors?

When Mary finally leaves the room and notices for the first time a patch of green pigment painted on a wall (acquaintance), does she acquire new knowledge? And then when someone tells her that the patch is green (knowledge by acquaintance), is there any new element added to her knowledge about green? The usual answer is yes. This indicates that there is a difference between "physical knowledge" (linguistic-quantitative description and experimental capacity of manipulation) of an element and the acquaintance with it. This difference is what is called qualia, or subjective qualities.

Jackson's "knowledge argument" thus leads to the thesis that there is nonphysical knowledge about the world. We note that this thought-experiment defines "physical knowledge" in a specific way. But accepting this definition, one concludes that the knowledge of qualia is "non-physical knowledge". But could one also conclude that qualia are non-physical entities? Such a view may be associated with David Chalmers (1996, p. 162), who considers a quale a "property" (p. 359). To conclude that qualia are non-physical, one would have to add another hypothesis to the argument, that "if something is knowable and if it is physical, then it is physically knowable". ${ }^{2}$ One infers from this that there is something nonphysical that is knowable, which would be qualia. Therefore, physicalism would be false.

Accepting Jackson's argument, the resulting dilemma is either to admit that physicalism is false, or to regard qualia as physical (rejecting Chalmers' hypothesis). This second alternative results in qualitative physicalism. A similar point is stressed by Owen Flanagan (1993, p. 98), who considers that the Mary's room thought experiment refutes linguistic physicalism, but not metaphysical (or ontic) physicalism.

\section{STRUCTURE AND MATERIALITY}

As an example, a computer model of a hurricane captures many relations between portions of water and wind within the hurricane, but the computer which realizes the modelling is not itself wet. Wetness is part of the "materiality" of the hurricane, involving real water. In the same token, we adopt the anti-functionalist ("psychosubstantialist") view that a computer model of the brain cannot have consciousness, because consciousness depends on a certain materiality that is present in biological tissues, but apparently not in silicon-based computers.

\footnotetext{
${ }^{2}$ Let us define the following predicates: Fx: " $\mathrm{x}$ is a physical thing"; Cx: " $\mathrm{x}$ is knowable"; Px: " $\mathrm{x}$ is physically knowable", where by definition: (1) $(\forall \mathrm{x})(\mathrm{Px} \rightarrow \mathrm{Cx})$; (2) ( $\forall \mathrm{x})(\mathrm{Px} \rightarrow \mathrm{Fx})$. Consider the following propositions: (3) ( $\exists \mathrm{x})(\mathrm{Cx} \wedge \neg \mathrm{Px})$ (Jackson's knowledge argument); (4) $(\forall \mathrm{x})((\mathrm{Cx} \wedge \mathrm{Fx})$ $\rightarrow \mathrm{Px}$ ) (lemma leading to Chalmers' hypothesis). From (3) and (4), one infers $(\exists x)(\neg F x)$.
} 
Thus, our hypothesis is that the seats of phenomenal consciousness have a structure and a materiality. The organizational structure $\Sigma$ is given by the spatial distribution of the neurons and supporting cells and molecules, and by their interaction, including the temporal spikes that flow through the neural networks. This organization is reproducible in a machine and may be theoretically represented (by Mary inside her room) and manipulated. The material component $\omega$ is specific to the biological tissue, and is probably lacking in silicon-based machines (which have their specific materiality, of course). This seems to be in agreement with Searle's (1992) "biological naturalism".

A view close to qualitative physicalism has been defended by phenomenalists such as Schlick (1918) and Russell (1927), who combine sensedata or sensorial elements with the view that physics only has access to the relations between things, a view sometimes called "physical structuralism" (or "structural realism"). Since, for Russell, the "percepts" are the only part of the physical world that we know in a non-abstract way, he concludes that the physical world is made of the same elements that we experience consciously. Schlick and Russell are not exactly materialists (which is the case of qualitative physicalism). Russell's views have had a recent impact in the philosophy of mind (see Alter \& Nagasawa, 2015), generating a class of views classified as "Russellian monisms", which considers that there exist "qualities", "quiddities", "inscrutables" or "thingsin-themselves" that permeate all of the physical world, and to which we don't have direct access, except for the sense data.

Qualitative physicalism maintains that a subjective sensation is identical to a real physical quality, probably of electrical/chemical nature, possibly localized in space, time and scale (see PESSOA, 2017). By extension, one may assume that matter is endowed with these qualities or quiddities, and that these combine in some complicated way in the brain tissue, generating the qualitative complex that we experience daily. This possibility is also considered by Herbert Feigl (1967), commenting on the "pan-quality-ism" proposed by Stephen Pepper.

Another tradition that is close to qualitative physicalism is what Chalmers (2015) called "panprotopsychism". This tradition is represented by the English physicist and philosopher William Clifford, who in 1878 defined what he called mind-stuff, present even at the atomic level, and the composition of which would generate conscious mind in human beings. This view had an influence on American neorealism, and the panprotopsychism of Durand Drake (1933) is very close to qualitative physicalism (see PESSOA, 2017).

\section{THE CHROMATIC SENSORIUM}

The colored-brain thesis implies that the subjective visual field exists in physical space, either as a direct physical screen (topologically distributed just like we experience it) or as a convoluted image. The first (and simpler) hypothesis amounts to the postulation of an identity between phenomenal space and time, on the one hand, and a region of physical space and time, on the other (in accordance 
with psychophysical isomorphism, see KÖHLER, 1943, pp. 61-2). According to this hypothesis, a chromatic quale emerges when a certain "pixel" of the subjective visual screen is fed with a certain pattern of spikes; a change in this pattern quickly changes the color that is subjectively (and physical-chemically) generated. Such patterns (which generate colors downstream) are probably produced in the visual cortical area V4. Only when such spatial-temporal patterns arrive at the hypothetical sensorium (the subjective arena, or Cartesian theater) are the physicalchemical qualities created, and somehow the core ego becomes aware of the scene (how this happens, of course, is still an open problem).

Such a screen may be either located in a small region (localizationism) or distributed over a large extent of the brain (holism). Following the first option, if one assumes that the density of information in the retina is comparable to that in the chromatic screen, such an internal screen might have a size of around $10 \mathrm{~cm}^{2}$. The retina has an area of around $10.94 \mathrm{~cm}^{2}$ (KOLB, 2007), generating a binocular visual field of around $200^{\circ} \times 135^{\circ}$, so the internal screen might occupy a region of approximately $4.0 \mathrm{~cm} \times 2.7 \mathrm{~cm}$. Another estimate can be made, of the size of the immediate correlate of conscious vision, by assuming that each subjective visual pixel is generated by a single biological cell. Considering the span of our binocular visual field of $200^{\circ}$ horizontally, and taking the limit of angular resolution of the human eye as being roughly 1 minute of arc (1/60 of a degree), if this limit corresponds to a single cell of around 4 micra, one computes the horizontal size of the visual field as being around $4.8 \mathrm{~cm}$, consistent with the previous estimate.

Such an image is most probably of an electrochemical nature, occurring in a special tissue (such as the reticular formation in nuclei of the thalamus) subject to spatial and temporal patterns of electrochemical spikes. In the case of subjective color sensations, Valberg (2001) and others have argued that the four (or six) basic colors, which constitute opposing colors in the sense of Hering (green-red, blueyellow, plus black-white), are not implemented in a pure form in the retina or in the lateral geniculate nucleus. This indicates that they are generated further downstream, and one might speculate that this takes place in the immediate neural correlate of vision (the visual sensorium). Since greenness and redness (for instance) cannot be instantiated at the same time, in the same pixel, this might suggest that some electrochemical system of the cell is either in an electrically positive or negative state (associated to greenness or redness), or in a neutral state, and in only one of such states at a given time (see HERING, 1913, pp. 59-61). According to our model, what determines these states is the temporal pattern of spikes that come into the cell from different external dendrites. Quantities generate qualities in a modulated electrochemical process. This would be different from the opponent cell structure in the parvocellular layers of the lateral geniculate nucleus (in the thalamus), where "red-ON cells", "green-OFF cells", "red-OFF cells" and "green-ON cells" process the incoming information.

Above the generation of qualitative chromatic pixels, one must also try to account for higher levels of representation, which identify smaller and larger patterns, ranging from localized corners all the way up to the figure's Gestalt or 
overall form. This might be implemented by layers of cells behind (or on both sides of) the layer of chromatic pixels.

In the philosophical literature, the chromatic screen (and analogous sensoria for other sense modalities) has been referred to as the "Cartesian theater" (Dennett, 1991, p. 107) or the "picture story" (PYLYSHYN, 2007, p. 121). The hypothesis of such a sensorium is criticized because, if there is a homunculus that is sitting in the audience and watching the picture show, how is one to explain what takes place inside the homunculus, without incurring an infinite regress? Of course one should not postulate a separate audience for the theater: somehow the core self must be built upon the Cartesian theaters (for the different modalities), breaking the separation between subject and object. The hypothesis presented here falls into what Dennett (1991, p. 207) has called "Cartesian materialism", the view "that there is a crucial finish line or boundary somewhere in the brain, marking a place where the order of arrival equals the order of 'presentation' in experience because what happens there is what you are conscious of".

\section{Measuring qualia}

Assuming that the model is correct, how could one manage to measure chromatic qualia? In principle, with nanoscopic techniques, one could capture all the patterns that fall on the tissue of the sensorium, and transmit the information to other media. But this does not capture the qualia. However, if the patterns are made to fall on a tissue of the same kind of materiality, typically inside another person's brain, this other person will have roughly the same subjective experience as the first person! This is how a subjective experience may be shared with other creatures of the same biological species, at least in a rough sort of way.

The notion of measurement, for qualia, is different from the usual measurements in physics, such as the ratio of two masses, which only capture the relations between entities (the aforementioned structural or organizational aspect of the world). As mentioned above, we consider that a quale is a "thing in itself" (involving a materiality). One cannot directly capture a quale and put the picture on the wall. But in principle it is easy enough to feed the patterns of one brain into another brain of similar material constitution. One could generate a Kodachrome photograph to be put on the wall, which causes in us a similar subjective experience as the one lived by another subject, but the photograph itself is devoid of chromatic qualia.

Ramachandran \& Hirstein (1997, pp. 432-33) arrived at a similar conclusion, inspired by talks with Francis Crick. They imagined a cable or "bridge of neurons" connecting visual area V4 of a person with normal vision to area V4 of a colorblind person due to problems in the retina, and concluded that the blind person would be able to experience the same chromatic qualia as the first person. This, however, does not mean that area V4 is the "chromatic sensorium", since it could be only an intermediate stage in the causal chain leading to the experience of qualia. Let us explore this considering another thought-experiment. 


\section{MODELLING OUALIA INVERSION}

To illustrate our model that qualia are produced when a certain pattern of neural spikes $\Sigma$ falls upon a certain region of the brain (the sensorium) of specific materiality $\omega$, consider Dennett's (1988, pp. 49-50) "intuition pump" (thought experiment) called the Brainstorm machine, in which someone (call him Dan) has access to the brain of another person (say Chloe) who inverts the color spectrum.

Suppose [...] there were some neuroscientific apparatus that fits on your head and feeds your visual experience into my brain [...]. With eyes closed I accurately report everything you are looking at, except that I marvel at how the sky is yellow, the grass red, and so forth. Would this not confirm, empirically, that our qualia were different? But suppose the technician then pulls the plug on the connecting cable, inverts it 180 degrees, and reinserts it in the socket. Now I report the sky is blue, the grass green, and so forth. Which is the 'right' orientation of the plug? Designing and building such a device would require that its 'fidelity' be tuned or calibrated by the normalization of the two subjects' reports - so we would be right back at our evidential starting point. The moral of this intuition pump is that no intersubjective comparison of qualia is possible, even with perfect technology. (DENNETT, 1988, pp. 49-50).

According to our model, at least two things can happen, as Chloe looks at the grass and has the subjective experience of red.

Case (I): assume the sensorium of both Chloe and Dan are the same: $\omega_{\mathrm{C}}=$ $\omega_{\mathrm{D}}$, but that Chloe sees the grass red because the spike train generated in area V4 and fed into the sensorium is different from the spike train generated in Dan's brain, which leads to the green quale: $\Sigma_{\mathrm{C}}$ (grass) $\neq \Sigma_{\mathrm{D}}$ (grass). Dan has access to Chloe's brain, but he can only receive her spike train $\Sigma_{\mathrm{C}}$, not having access to the material substrate $\omega_{C}$. As $\Sigma_{C}$ falls on $\omega_{D}$, Dan will have the same subjective color experience as Chloe, i.e. he will see the image of the grass as red, since both sensoria are identical (and supervenience guarantees that the identical brain states generate identical mental states).

Case (II): assume the spike trains generated for both of them are the same, $\Sigma_{\mathrm{C}}=\Sigma_{\mathrm{D}}$, when looking at grass, but that Chloe has a red experience because her material substrate (sensorium) is in a different chemical state from that of Dan, so that $\omega_{C} \neq \omega_{D}$. In this case, Dan will receive from Chloe the same spike train that he usually sees when looking at grass, so his experience of the grass Chloe is seeing will be green, i.e. different from Chloe's subjective experience, which is red. He will have no clue that she is subjectively inverting the spectrum.

Case (III): there are other variations in which $\omega_{\mathrm{C}} \neq \omega_{\mathrm{D}}$ and $\Sigma_{\mathrm{C}} \neq \Sigma_{\mathrm{D}}$, but we will ignore them.

The situation described by Dennett would have to correspond to case (I), since Dan marvels at the color changes while having access to Chloe's brain (in case II he notices no change). In this case, the qualia that both of them experience 
when looking directly at grass are clearly different. But the quale Dan experiences when looking inside Chloe's head is the same as that which she is experiencing at the time (contrary to what happens in case II).

Now, the assumption that the technician switches the plug really doesn't apply to case (I), since we have assumed that both sensoria are identical, and because the spike train is a mechanical (geometrical) property of the world, the determination of which does not depend on previous calibration of the subjects' reports.

In case (II), however, as noted above, Dan would have no way of knowing what color Chloe is experiencing. Neuroscientists could infer that she might be having a different experience, by noticing chemical differences in her sensorium (in relation to Dan's). But exactly what qualia each is experiencing is something only theory could tell us (up to its degree of confirmation). A third party might conclude that she is experiencing the same quale as either Chloe or Dan, as long as their sensoria are in the same physical-chemical state.

\section{PROJECIIONS IN TIME AND SPACE}

How is it that we project the visual scenery of our environment as something much larger than our bodies, given that the actual size of the representation we experience is of the order of only $10 \mathrm{~cm}^{2}$ ?

To guide our reasoning, let us start with the notion of the antedating of time, which is connected to the definition of what is "now". According to Libet et al. (1979), it takes a small "period of adequacy" (between a fifth of a second and half a second) for a perceptual stimulus (such as a tactile pinch in the hand) to become conscious. Besides that, they showed that we "antedate" the occurrence of the perceptual event back to the past (by an amount equal to the period of adequacy), so as to correct our subjective ordering of events. Direct stimulus to the cortex is not antedated, so it was in relation to this that the mechanism of antedating was discovered. The hypothesis suggested by the authors was that a "marker" for the perceptual event was registered at the thalamic level at the time the stimulus first arrived there, so that the relative orderings of different perceptual events could be consciously evaluated in a correct manner after the period of adequacy.

We could say that this is one more example of how natural selection finetunes "the subjective construction of the representation of the world" so as to fit to the actual world. Since percepts of different intensities might have different periods of adequacy, such a mechanism guarantees in a simple way that the marks of the temporal ordering of the stimuli follow their times of arrival at the thalamus (before proceeding to conscious processing).

From a different perspective, this situation brings in the question of how to define the "present" time. To define it as "now" is circular. An ostensive definition such as "the time that I am saying the word "now" (or seeing a flea leap) requires one to mutter a word (or consciously process the observation of the leap), so that 
the conscious perception of this act is delayed by the period of adequacy. Thus, the present cannot be captured simply by conscious observation. One has to introduce theoretical considerations, so that "the present associated with the flea's leap" would have to be "half a second before the time of conscious awareness of the leap", or "the time Libet's perceptual mark is registered in the thalamus", or a comparison with some other event.

The antedating of time is an instance of a "projection", i.e. the association of an object to a spatio-temporal setting established in relation to our body. What would be an analogous projection for the perception of space? Libet et al. (1979, p. 221) explore the analogy, but focus on the recognition that "the spatial form of a subjective sensory experience need not be identical with the spatial pattern of the activated cerebral neuronal system that gives rise to this experience". This issue bears on Köhler's aforementioned psychophysical isomorphism, and its alleged refutation in experiments on the neocortex, but it is still an open problem, given that the hypothetical visual sensorium has not yet been identified (and is probably not in the primary visual cortex).

The analogy with temporal antedating that we would like to stress is the subjective projection of our small "chromatic screen" to a size much larger than our own bodies. In other words, we experience our visual field as being outside our bodies, which is consistent with our actions in the world, but in fact (according to qualitative physicalism) it occupies a small region in our brains. Pathologies in this ability for projection seem to lead to certain forms of the Alice-in-Wonderland syndrome.

Besides the subjective construction of visual space directly from a small spatial patch in our brains, one might also mention the spatial representation that organizes our bodily senses, including the senses of touch, pressure, pain, temperature, vibration, and proprioception. The pathways arising from different parts of the body are spatially organized in the brain in a form that resembles the body, in regions called "somatosensory homunculi", to be found in the cortex (parietal lobe), thalamus (ventralis posterior nucleus) and cerebellum. In fact, there is a continuous somatotopical tissue organization all the way from the brainstem to the other regions of the brain, along the ascending lemniscal and anterolateral pathways. The seat of bodily consciousness (the somatosensory sensorium) could be located anywhere in these pathways, and once again the thalamus seems a good candidate, as stressed by a few authors, such as Bogen (1995) and Ward (2011).

An object of the sense of sound may be projected on external space, but the "tonotopic" organization of information which gives rise to subjective pitch is done roughly in one mirror-symmetric spatial dimension in Heschl's gyrus of the auditory cortex (DA COSTA et al., 2011).

As for the sense of smell, the thalamus does not seem to be a good candidate for the seat of conscious awareness. Around 400 olfactory receptors generate patterns in the glomerular layer of the olfactory bulb, which is further processed in the three-layered olfactory cortex. After this, there is "only a small contingent of 
fibers going to the mediodorsal thalamus" (SHEPHERD, 2005, p. 166), with most of the pathway leading directly to the prefrontal cortex. There is no subjective projection of odors onto the "somatosensory-visual" external space, but Kumar et al. (2015) have drawn an "odor network", which represents subjective similarities between classes of odors.

\section{CONCLUSION}

The metaphysical solution to the mind-brain problem provided by qualitative physicalism (the colored-brain thesis) interprets qualia as real physical entities. Far from settling the problems in the field, the approach has given rise to a heuristics of investigation, based on the postulated identity between "phenomenal time and space" and "a region of physical time and space", which is typical of Cartesian materialism. A fundamental distinction is made between the organizational structure $\Sigma$ of a physical process and its materiality $\omega$. We have postulated that qualia arise from a material cellular substrate, when specific spatiotemporal patterns of electrochemical spikes are fed to the substrate. The issue of how to measure a quale is solved in a direct manner, by recognizing that the measurement of the pattern of spikes can generate a similar quale if it is fed to another identical material substrate, i.e. another human brain. Our model was applied to the Brainstorm-machine thought experiment, involving qualia inversion, yielding two distinct and interesting results. While neuroscience has not yet solved the issue of the immediate neural correlates of consciousness, we have explored some possibilities from a localizationist perspective. ${ }^{3}$

\section{REFERENCES}

ALTER, Torin \& NAGASAWA, Yujin (eds.). Consciousness in the physical world: perspectives on Russellian monism. Oxford: Oxford University Press, 2015.

BOGEN, Joseph E. On the neurophysiology of consciousness. I. An overview. II. Constraining the semantic problem. Consciousness and Cognition, v. 4, p. 52-62, 137-58, 1995.

BORING, Edwin G. The physical dimensions of consciousness. New York: Century, 1933.

CASE, Thomas. Physical realism: being an analytical philosophy from the physical objects of science to the physical data of sense. London: Longmans, Green \& Co., 1888.

\footnotetext{
3 This paper is based on the talk "Como medir um quale?", given at the XI International Brazilian Meeting on Cognitive Science (EBICC), in October 30, 2017, and on the lecture "Explorando o materialismo cartesiano", given by telecommunication at the Encontro Cognição \& Linguagem, in November 6, 2018, both at the University of São Paulo. Much of the research stems from a grant from the Conselho Nacional de Desenvolvimento Científico e Tecnológico (CNPq - Bolsa de Produtividade). I am also grateful for the welcome given by the Dept. of History \& Philosophy of Science and Medicine, Indiana University, where this version of the text was completed, and also for the useful comments of the referees.
} 
CHALMERS, David J. The conscious mind. New York: Oxford University Press, 1996.

Panpsychism and panprotopsychism. The Amherst lecture in philosophy,

pp. $2013.35,2$ Available at: http://www.amherstlecture.org/chalmers2013/chalmers2013_ALP.pdf. Reprinted in ALTER \& NAGASAWA (2015), pp. 246-76.

DA COSTA, Sandra; VAN DER ZWAAG, Wietske; MARQUES, José P.; FRACKOWIAK, Richard S. J.; CLARKE, Stephanie \& SAENZ, Melissa. Human primary auditory cortex follows the shape of Heschl's gyrus. Journal of Neuroscience, v. 31, p. 14067-14075, 2011.

DENNETT, Daniel. Quining qualia. In: MARCEL, Anthony J. \& BISIACH, E. (eds.). Consciousness in contemporary science. Oxford: Clarendon, 1988. pp. 42-77.

Consciousness explained. New York: Little, Brown \& Co., 1991.

DRAKE, Durand. Invitation to philosophy. Boston: Houghton Mifflin, 1933.

FEIGL, Herbert. Russell and Schlick: a remarkable agreement on a monistic solution of the mind-body problem. In: Roberts, George W. (ed.). Bertrand Russell memorial volume. Oxfordshire: Routledge, 1975. pp. 321-38.

FLANAGAN, Owen J. Consciousness reconsidered. Cambridge (MA): MIT Press, 1993.

HERING, Ewald. On the theory of nerve-activity. In: Memory: lectures on the specific energies of the nervous system. 4th ed., enlarged. Lecture given in May, 1898, in Leipzig. Chicago: Open Court, 1913. pp. 43-70.

JACKSON, Frank. Epiphenomenal qualia. Philosophical Quarterly, v. 32, p. 127-36, 1982.

KÖHLER, Wolfgang. Gestalt psychology. 2nd ed. New York: Liveright, 1943 [First edition: 1929].

KOLB, Helga. Facts and figures concerning the human retina, 2007. Available at: https://www.ncbi.nlm.nih.gov/books/NBK11556/.

KUMAR, Ritesh; KAUR, Rishemjit; AUFFARTH, Benjamin \& Bhondekar, Amol P. Understanding the odour spaces: a step towards solving olfactory stimulus-percept problem. PLOS One, v. 10, n. 10, paper e0141263, 2015.

LIBET, Benjamin; WRIGHT, Elwood W., Jr.; FEINSTEIN, Bertram \& PEARL, Denies K. Subjective referral of the timing for a conscious sensory experience: a functional role for the somatosensory specific projection system in man. Brain, v. 102, p. 191222, 1979.

PESSOA Jr., Osvaldo. A tese do encéfalo colorido. Forthcoming in Estudos Filosóficos (São João del-Rei), 2017.

PLACE, Ullin T. Identity theories, 2000. Unfinished manuscript, edited by S. Schneider, available at the website $A$ field guide to the philosophy of mind: http://host.uniroma3.it/progetti/kant/field/mbit.htm. 
PRICE, Henry H. Perception. London: Methuen, 1932.

PYLYSHYN, Zenon W. Things and places: how the mind connects with the world. Cambridge: MIT Press, 2007.

RAMACHANDRAN, Vilayanur S. \& HIRSTEIN, William. Three laws of qualia: what neurology tells us about the biological functions of consciousness, qualia and the self. Journal of Consciousness Studies, v. 4, p. 429-58, 1997.

RUSSELL, Bertrand. The analysis of matter. New York: Harcourt Brace \& Co., 1927.

SCHLICK, Moritz. General theory of knowledge. Translation by A.E. Blumberg of the 2nd German edition of 1925 (1st ed. 1918). New York: Springer, 1974.

SEARLE, John. The rediscovery of the mind. Cambridge: MIT Press, 1992.

SHEPHERD, Gordon M. Perception without a thalamus: how does olfaction do it? Neuron, v. 46, p. 167-9, 2005.

STUBENBERG, Leopold. Consciousness and qualia. Amsterdam: John Benjamins, 1998.

VALBERG, Arne. Unique hues: an old problem for a new generation. Vision Research, v. 41, p. 1645-57, 2001.

WARD, Lawrence M. The thalamic dynamic core theory of consciousness. Consciousness and Cognition, v. 20, p. 464-86, 2011.

Recebido em: 06-03-2019

Aceito para publicação em: 25-06-19 